\title{
SOCIAL EQUALITY AND CHRISTIAN LIFE IN PAUL'S FIRST LETTER TO THE CORINTHIANS
}

\section{ABSTRACT}

This contribution seeks to clarify how the category of eschatological equality in 1 Corinthians is to be ascertained. Is equality, in this instance, to be understood as the annulment of status differences within the Christian congregation, or does it belong to an eschatological plan of an ideal or utopic world? Is the new Christian existence of the Corinthians conceived as real, as outwardly visible or as socially perceivable? This study is aimed at understanding the theological construction connected with these questions by interpreting the paradigmatic relation of the

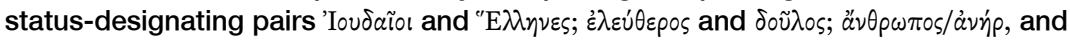
$\gamma \cup \nu \eta \dot{~(o r ~ a ̈ \rho \sigma \varepsilon v ~ a n d ~} \theta \tilde{\eta} \lambda u$ ) within the Pauline argument.

\section{INTRODUCTION}

Every individual is automatically, by birth, placed within a certain social context. Through this destiny, each individual obtains a certain social status, rights, obligations, educational opportunities, participation and integration within this society, freedom, power, influence, and honour. Notwithstanding upward mobility through, for example, accomplishments, education, or wealth, a fundamental inequality results from this natural status (cf. Koch 1987:1177-1182). Ideal equality, ideal equal status, and ideal treatment of all human beings, regardless of their differences, are accordingly not concrete or experiential aspects of reality. They are sought after but unattainable. This is true for both the present and the earliest history of Christianity.

Prof. Michael Tilly, Evangelisch-Theologische Fakultät, Eberhard Karls Universität, Tübingen \& Research Associate, Department of New Testament Studies, Faculty of Theology, University of Pretoria. E-mail: michael.tilly@uni-tuebingen.de 
In the introduction to his commentary on First Corinthians, Lang writes:

Gott hat im Kreuz Christi die sündige Menschheit mit sich versöhnt ... und durch seinen Geist die Freiheit des Glaubens begründet. Der alten Welt ist der Todesstoß versetzt; in Christus ist die neue Welt Gottes angebrochen, an der die Christen als neue, die alten Unterschiede von Juden und Griechen, Sklaven und Freien, Männern und Frauen überwindende Gemeinschaft bereits jetzt im Glauben teilhaben (Lang 1994:6; cf. also Schnelle 2003:490-492).

This statement describes pithily a revelatory context for eschatological equality as Christian hope and the fundament and criteria for a Christian ethics. However, this simultaneously raises the question as to how the category of eschatological equality in 1 Corinthians is to be ascertained. Is equality to be understood as a dynamic equality, as the annulment of a system of contemporary dichotomies, antitheses and status differences within the congregation? Is it to be achieved as an interpersonal égalité endowing social ideas and as an unconditional relativisation of the existing differences, boundaries and conventions already present in the ecclesiastical life of this world? Or does it belong - understood as status equality, which does not materially abolish the existing inequalities - to an eschatological plan of an ideal or utopic world? Is the new Christian existence of the Corinthians conceived as real, as outwardly visible, or as socially perceivable? What consequences should one draw from the fact that the inherent differences vis-à-vis salvation are irrelevant?

This contribution seeks to clarify the theological construction connected with these questions, by interpreting the paradigmatic relation of the status

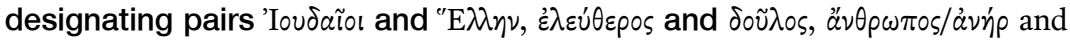
$\gamma \cup \nu \eta \dot{~(o r ~ a ̈ \rho ~} \sigma \varepsilon \nu$ and $\theta \tilde{\eta} \lambda u$ ) within the argument of 1 Corinthians. As a starting point for the Pauline reference to these concepts - in its context and in the social structures of the provincial capital Corinth - one can refer to the clearly discernible social status differences in Galatians 3:28, an explicit pre-Pauline baptismal tradition from a Hellenised Jewish-Christianity. ${ }^{1}$ The new relation to God acquired through baptism constitutes the new status of the believer (cf. Schnelle 2013:332-337); the new existence ह่ X X

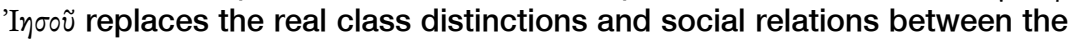
(subjectively understood) oppositions "Jew" and "Greek", "slave" and "freeman" and the semantic opposition (expressed through the adjectives) "male" and "female" (cf. Zimmermann 2013:380).

As a unifying dimension, this new existence transcends the aforementioned differences. In 1 Corinthians 12:13, Paul takes up the same tradition,

1 Cf. Col. 3:11; Lührmann (1978:65-68); Wolter (2011:136-138). 
omitting the third opposition. Furthermore, the notion of equality or comparability of Jews and Greeks is expounded in 1 Corinthians 1:22ff., 7:18f. (in a digression on the relation between man and woman), implicit in 1 Corinthians 9:20f., and broached in 1 Corinthians 10:32. Paul writes of the opposition of free and slave in 1 Corinthians 7:21-23 and 9:19. Aspects of the comparability of male and female are found accumulated in 1 Corinthians 7 (especially 7:1b-4) and 11 (especially 11:11f.).

This article has three parts. First, it delineates the literary macro-context and the theological basis from which Paul argues. The main body of this contribution explores the contextual significance of the above opposing pairs in 1 Corinthians. Summaries and theses conclude the article.

\section{EQUALITY AS AN ETHICAL IMPLICATION OF THE PAULINE THEOLOGIA CRUCIS}

1 Corinthians addresses concrete issues of faith and life in a religious, cultural and socially heterogeneous urban congregation, and attempts to respond to them utilising a fundamental theological argumentation (cf. Lampe 2013:172-185). Despite the thematic multiplicity, the letter retains its unity through Paul's immediate response to the Corinthian problems (1 Corinthians 1-4), mitigated through his theologia crucis. Owing to the expansion of Christianity in the urban eastern Mediterranean region and corresponding to its strong integration capacity and to the transnational, transcultural character and multi-social strata nature of the Pauline churches, the mostly gentile congregation in Corinth may be regarded as a heterogeneous community that participated in the opportunities for upward mobility, in which different individuals and norm conceptions clashed with one another and which included certainly not only members of the urban precariat, but also some people of higher social standing with more property, power, education, a distinguished parentage, social status, influence, and honour. ${ }^{2}$ This ethnic-genealogical, economic and social inequality of the inhomogeneous congregation led rather rapidly to theological and social-ethical tensions (cf. Schmeller 1995:92ff.).

In this letter, Paul contends with theologically motivated schisms and the deviating interpretations of the Christian kerygma in Corinth. $\mathrm{He}$ combats these schismatic tendencies and the ethical consequences of an (according to him, strongly misguided) understanding of the Christian message as an esoteric wisdom doctrine, which results in the practice of putative rights or specific conduct; this he combats with recourse to the

2 Cf. 1 Cor. 1:14; Rom. 16:23; 1 Cor. 1:16; 11:22; 16:15ff.; 16:1-4. 
unity of Christians, which is constituted only in Christ and inherited only by baptism.

Paul counters the $\sigma \chi^{i} \sigma \mu \alpha \tau \alpha$ in the congregation with this unity established in Christ. The apostle to the Gentiles appeals above all to the Greek sensibility for equality among the educated Christians in Corinth, who were integrated into the pagan urban society (cf. 1 Thess. 2:14f.), using the

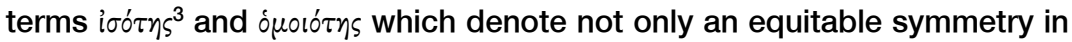
the context of traditional Jewish solidarity, ${ }^{4}$ but are also utilised in GrecoRoman constitutional law and jurisprudence. ${ }^{5}$ Furthermore, one must mention the Cynic-Stoic concept of the natural equality of all human beings regarding fate and in the participation in the reason, which orders the world, regardless of the differences of ancestry, status and gender as part of the philosophical historical context and as part of the existing cultural identity of the Corinthians. ${ }^{6}$ God's action in Christ stands, according to Paul, in direct contrast to all human principles of action and affects their relativisation (1 Cor. 1:27f.). Already the prescript of 1 Corinthians hints at this important aspect of Paul's concept of ecclesiology. Paul calls the

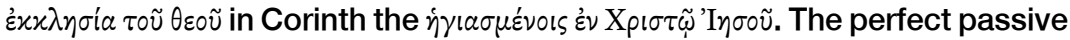
participle points to the fundamental cultic-eschatological dimension of congregational life. At the same time, it accentuates its autonomy from worldly norms; the explanatory addition emphasises the placement of this sanctification $^{7}$ in the radical new salvific reality, which is realised through the crucifixion and resurrection of Jesus Christ. Being $\varepsilon \nu \mathrm{X} \rho \sigma \tau \tilde{\omega}$ is the key to this new existence.

The crucified and exalted Christ is, for the apostle to the Gentiles, the foundation, rule and goal of the Christian congregation. The beginning of the personal affiliation with this Spirit-filled salvific status, which Paul calls $\sigma \tilde{\omega} \mu \alpha$ in 1 Corinthians 12:13-27, finds emblematic expression in baptism; ${ }^{8}$ through baptism, human beings reach the salvific realm of communion

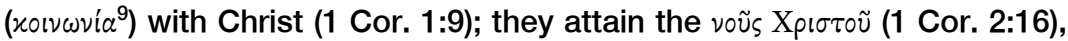
and from it emerges a new social situation and ethical system.

3 Cf. 2 Cor. 8:13f. (collection); Col. 4:1.

4 Cf. the citation of Ex. 16:18 LXX at the end of 2 Cor. 8:13-15.

5 Cf. Polybios (Hist. 2,38,6-10); Pollmann (2012:61f.).

6 Cf. Aristoteles (Pol. II 2.6); Philo of Alexandria (De specialibus legibus 4, 165).

7 Cf. Dan. 7:18.22; Kratz (2006:242f.).

8 Cf. Is. 32:15; Ez. 36:25f.; Joel 3:1f.

9 Paul uses xolvwvía as a soteriological term, which designates the human proportion of Christ's sanctifying achievement. Cf. Zeller (2010:338). 
Paul utilises the (independently interpreted) illustration of the organism (which was also understandable to the pagan addressees) ${ }^{10}$ to characterise his ecclesiology of the Christian congregation as containing many principally equal members, regardless of their qualitative divergence. The common reference to Christ and his salvific act accounts for the unity of the congregation.

\section{ASPECTS OF EQUALITY IN 1 CORINTHIANS}

\subsection{Equality of Jews and Greeks}

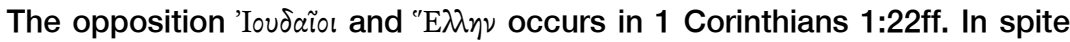
of the gentile Christian audience (cf. 1 Cor. 12:2), Paul retains the Jewish perspective ${ }^{11}$ and does not use the pagan Hellenistic distinction "Greek and Barbarian". ${ }^{2}$ Both Jews and Greeks, differentiated within salvation history, want to observe evidence for the divine truth - the Greeks in the form of rhetorical argumentation, and the Jews in the form of external proofs. A classification of Torah observance and Judaism cannot be discerned in this instance; apparently, the problem of Israel's salvific advantage or the existence of legalists in Corinth was not discernible. The present tense verbs in these verses, ai present time of the statement.

The adversative $\dot{\eta} \mu \varepsilon \tilde{\varsigma} \delta \delta^{\text {in }}$ in verse 23 introduces the intended juxtaposition. The equality of the sign-seeking Jews and the wisdom-seeking Greeks (in this instance, as partes pro toto for all Gentiles) corresponds to the

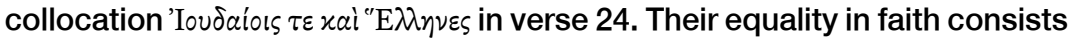
not - expressed positively - in the abolishment of their ethnic religious ancestry or their differing election, but - expressed negatively - in the fact that they judge the crucifixion according to the criteria of their own world view. God however, according to Paul, acts contrary to human imagination and expectation.

The double apposition in verse 24b emphasises the actual contrast.

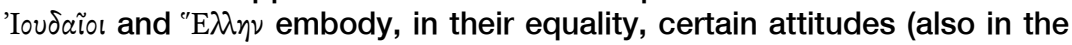
congregation) that contradict the demand of faith and the new status $\dot{\varepsilon} v$ Xpı $\tau \tilde{\omega}$. Therefore, one should not differentiate - "vertically" - between

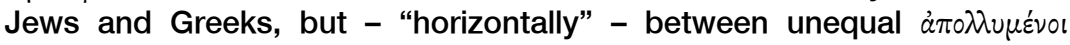

10 Cf., for example, Plato (Politeia VIII 556e. 567c); Livius (Ab urbe condita II 32f.); Plutarch (Solon XVIII 5).

11 Also Rom. 1:16.

12 Cf. Rom. 3:22 (used polemically against "the Jews"); 10:12. 


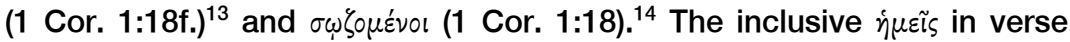
23f. refers to the ones called $x \lambda \eta \tau 0^{\prime 15}$ in verse 24 . It includes Jews and Greeks ${ }^{16}$ and contrasts exemplarily the "called" in Christ from the Jews and Greeks in their respective community (in v. 25 concise as $\alpha \dot{\nu} \theta \theta^{\prime} \omega \dot{\pi} \pi \circ$; in v. 29 as $\pi \tilde{\alpha} \sigma \alpha \sigma \alpha \dot{\alpha} \xi)$. Even the rejection of the word of the cross motivates one form of equality.

In 1 Corinthians 7:18f., the equality of circumcised Jews and uncircumcised Gentiles is discussed in the context of a Pauline excurse on the correct relationship of Christians to the social ranks in this world (1 Cor. 7:17-24). Circumcision per se is, in this context, beyond dispute; this example is probably not part of the current problems in Corinth. Both parallel-formulated sentences recognise circumcision and noncircumcision as a religious difference, whose equality consists of the fact that both are abrogated in favour of the stipulated new life according to

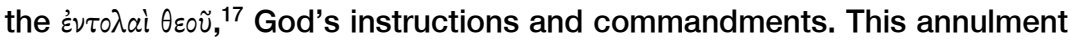
of the inequality is, however, not a compromise, but a radical new situation. Both "pre-Christian" statuses of the called, who are now $\dot{\varepsilon} v$

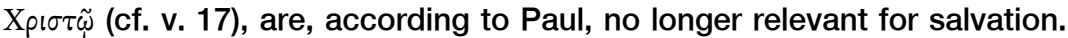
Moreover, God's eschatological intervention relativises their previous salvation-historical polarity.

In 1 Corinthians 9:20f., another aspect of the equality of Jews and Greeks is transferred to Paul's preaching of the gospel. Syntactically referring to of $\pi \lambda \lambda^{\prime}$ ov $\varepsilon \varsigma$ of verse 19, the addressees of Paul's evangelisation, the apostle to the Gentiles' affiliation to both groups through Christ and the law are set on equal footing (cf. Rom. 1:16). With regard to Paul's missionary custom, the

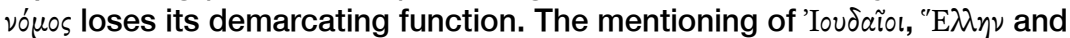

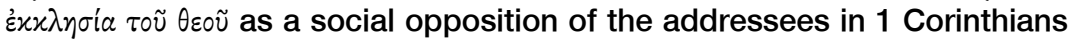
10:32 corresponds to the recognisable "horizontal" demarcation between the equality in the world and the equality $\dot{\varepsilon} \nu$ X 1 Corinthians 1:18ff.

In the context of the pre-Pauline baptismal tradition in 1 Corinthians 12:13, Paul emphasises equivalence and unity of baptised Jews and Greeks in the congregation. ${ }^{18}$ The concentration upon the unity of all baptised and

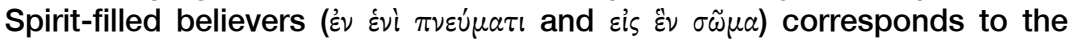

13 Cf. 1 Cor. 8:11; 10:9f.; 15:18.

14 Cf. 1 Cor. 3:15; 5:5; 7:16; 9:22; 10:33; 15:2.

15 Cf. v. 21: oi $\pi เ \sigma \tau \varepsilon \dot{o v \tau o l . ~}$

16 Cf. the neuter participles in v. 28.

17 Cf. Gal. 5:14; Rom. 13:8-10.

18 Inclusive $\eta \mu \varepsilon \tilde{\varsigma} ;$ cf. 1:23f. 
aorist forms $\dot{\varepsilon} \beta a \pi \tau i \sigma \theta \eta \mu \varepsilon \nu$ and $\dot{\varepsilon} \pi \circ \tau_{i}^{\prime} \sigma \theta \eta \mu \varepsilon \nu$, which accentuate the uniqueness of baptism as a punctual event in the past. The structure and values of this world, according to Paul, have, in light of the new "Frontverlauf", for these Jews and Greeks no longer salvific relevance; in this instance, it is also a matter of equality $\dot{\varepsilon} \nu \mathrm{X} \rho \sigma \tau \tilde{\omega}$ as integral part of the congregation.

\subsection{Equality of slave and free}

1 Corinthians 7:21-23 continues the discussion of the adequate relationship of the Christians to the statuses of this world, taking up the symmetry in verse 18f. In the form of a direct address, verse 21 a qualifies the significance of the slave status of a Christian, i.e. his relation to his master as a possession without intrinsic rights, through his calling into the new salvation status $\dot{\varepsilon} v$ xupí $\omega$. The translation and interpretation of verse $21 \mathrm{~b}$ are problematic; there is no object of the aorist imperative

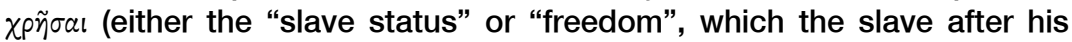
change of status, should utilise). The use of the aorist tense speaks for the latter interpretation. The immediate context (the following verse) and the pragmatics of the text (the current consoling encouragement) tend to speak for the former option. ${ }^{19}$

As a chiastic parallelism, Paul explicates in verse 22 the paradoxical correlation between freedom (qua birth or emancipation or manumission) and slave status of a Christian in his relation to Christ. The apostle justifies herewith the previous statement. The slave $\varepsilon^{2} \nu$ xp í $\omega x \lambda \eta \theta \varepsilon i s$ is a manumitted

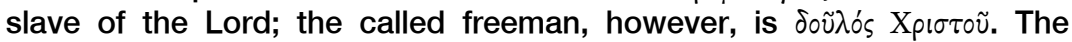
real social status of a slave belongs to this perishing world and is as irrelevant for salvation in his new life and relationship with Christ as the possibility of his upward mobility in society through manumission or his efforts for social acceptance, external and public citizen freedoms and privileges. Again Paul sees the equality of the slave and freeman in the fact that the significance of both statuses is symbolically abolished, not in the overarching social and judicial reality, but in their internal relation to Christian existence, through baptism.

Paul seems to expect from his addresses in Philemon 15f. that Philemon relinquishes, in the context of his congregation, the conventional asymmetrical status vis-à-vis his (perhaps runaway) slave Onesimus.

Verse 23 shows clearly that Paul does not understand the Christian's new desirable inner freedom as an autonomous and abandoned condition,

19 The conjunction zi xaí has a concessive meaning. 
but as a salvific ownership change with Christ as the new patron. ${ }^{20}$ The

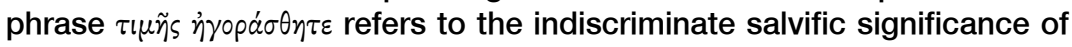
Jesus' crucifixion for Christian slaves and freemen; outside of Christ's dominion, only one option exists, the equality in a general status of being

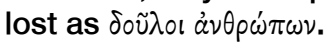

1 Corinthians 9:19 transfers the relation of the opposition $\delta \circ \tilde{\lambda} \lambda \circ \mathrm{-}-\dot{\varepsilon} \lambda \varepsilon \varepsilon^{\prime} \theta \varepsilon \rho \circ$ implicitly to the Pauline preaching of the gospel. The eschatological freedom of the apostle to the Gentiles, already mentioned in 1 Corinthians 9:1, is paradoxically the completion of his mission as a slave to all ( $\pi \tilde{\alpha} \sigma \nu \nu) .{ }^{21}$ Paul's personal relinquishment of rights qualifies his obligation as $\delta 0 \tilde{\nu} \lambda \circ \varsigma \alpha \dot{\alpha} \nu \rho \omega \dot{\omega} \pi \omega \nu$ and places his ministry squarely in the emulation of the crucified saviour. ${ }^{22}$

The emphasis on the unity of the contrasting terms $\delta \circ \tilde{\nu} \lambda_{0}$ and $\dot{\varepsilon} \lambda \varepsilon \dot{\theta} \theta \varepsilon p \circ$ in the reception of this Hellenistic Jewish-Christian baptismal tradition in 1 Corinthians 12:13 intends to accentuate the indiscriminate equality within the ecclesiastical Christuswirklichkeit as a new salvation status, from God in the light of the era-changing power of the Christ event.

\subsection{Equality of male and female}

The main topic of 1 Corinthians 7 , in which Paul is probably answering the Corinthians' enquiry (1 Cor. 7:1a), is the question as to whether being married or single constitutes the best form of their calling within the Christian congregation. At the beginning of the first argument about the position of married Christians (1 Cor. 7:1-24), Paul repeatedly utilises, in his general instructions in verse $1 \mathrm{~b}-5,{ }^{23}$ the opposition $\alpha \nu \theta \rho \omega \pi \circ \varsigma / \alpha \nu \eta \dot{\rho} \rho$ and $\gamma u \nu \eta \dot{~}$. After he commends sexual abstinence for the male (v. 1), the two-pronged statement in verse 2 concedes the equality of male and female regarding reciprocity of their corporality and their marital companionship. The syntactical symmetry of both chiastic sentences in verse 3f. underscores

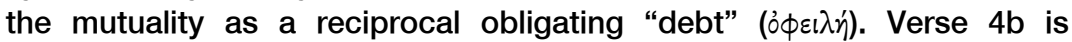
extraordinary; the dominion of the female over her husband's body does not correspond to either Jewish ${ }^{24}$ or Roman conventions. ${ }^{25}$ Many have attempted to interpret 1 Corinthians 7:1b-5 (also Gal. 3:28) as a statement about the equality of the sexes, towards an egalitarian abolishment of the traditional androcentric and patriarchal order within the Corinthian

20 Paul identifies himself as a "slave of Christ" in 2 Cor. 4:5; Gal. 1:10; Phil. 1:1, and Rom. 1:1.

21 Cf. Gal. 5:1.13.

22 The participle clause $\varepsilon^{\lambda} \lambda \varepsilon \dot{\theta} \theta \varepsilon \rho \circ \varsigma \grave{\omega} \nu$ has a concessive meaning. Cf. Phil. 2:7.

23 The corresponding v. 8 suggests that v. 1b already contains Paul's answer.

24 Cf. Gen. 3:16; Loader (2004:121f.).

25 Cf. Rom. 16:1, 7; Loader (2012:106f.). 
house churches and in favour of the real social emancipation of the female within the congregation. ${ }^{26}$ This interpretation of Paul's argument and its use as an authoritative basis for current church practice projects, in my opinion, a - legitimate - concern of Christian living in past and present, anachronistically onto the historical and situational provisory Bible text.

On the one hand, in 1 Corinthians 7, Paul argues apparently against ascetic tendencies within enthusiastic groups in the Corinthian congregation. On the other hand, his argumentation in this capital is shaped by his expectation of an imminent $\pi \alpha$ povoi $a .{ }^{27}$ Paul attempts, in the tense relation between creation principles and redemptive principles, to legitimise the equality of male and female in the congregation with reference to their common constitution as created beings and simultaneously to relativise their significance as an anticipation of the expected fate sub specie aeternitatis.

The dogmatically formulated estimation of sexual asceticism in 1 Corinthians 7:1 evinces points of contact with the Stoic-influenced concept of the adult male, who is rational, moderate, and able to transcend all affects, and with the Hellenistic ideal of living felicitously an abstemious and contemplative life. However, the Greco-Roman world often associated unbridled sexual activity and lust with feminine inferiority and weakness. ${ }^{28}$

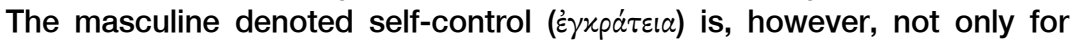
educated Greeks and Romans an ideal behaviour trait, but Paul also regards it as an important Christian virtue (1 Cor. 7:9; 9:25; Gal. 5:23; cf. Phil. 4:11ff.). Corresponding to the known myths and anthropogenetic conceptions both in the Jewish ${ }^{29}$ and in the pagan ${ }^{30}$ traditions, the movement of the human to the divine was often regarded as a movement from the feminine to the masculine and from the sexual to the asexual. ${ }^{31}$

Paul also considers the gender difference between male and female rooted in creation not as a dichotomy but as a scale (cf. 1 Cor. 11:3). ${ }^{32}$ Against this background, the paraenetic statements in 1 Corinthians 7:2-4 form pragmatic instructions for the Corinthians' Christian existence and

26 Cf., for example, Sellin (1987:3000); Strecker (1999:349-361).

27 Cf. 1 Cor. 7:7, 16, 26, 28ff.; 1 Cor. 10:11; 15:51.

28 For example, Seneca (Controversiae I 8-9); Philo (Quaestiones in Exodum I 8); Soranus (Gynaeciorum liber I 7.30). Cf. Martin (1995:200-204.)

29 Cf., for example, Gen. 2:18.22 and especially the presentation of the creation of male and female in Gen. 1:26-28 LXX; Philo (Fug. 51f.).

30 Cf., for example, Aristoteles (Eth. Nic. VII 1.29); Plato (Symposion 189-193; Rep. 381a).

31 Cf. Sissa (2008:165-191).

32 Cf. 2 Clem. 12:2 and the Gospel of Thomas, Logion 114. 
for marriage as an institution of this perishing world. ${ }^{33}$ They represent the notion of an eschatological equality of the sexes as an annulment of their social differences at best regarding the emphasis on the reciprocity of their relation to one another. Therefore, Paul does not advocate a rearrangement of the conventional gender roles of male and female in 1 Corinthians 7.

In addition, in 1 Corinthians 11, one encounters the notion of the primacy of the male due to his being the immediate image of God. The counterparts in verse 3 statically determine a relational consecution of the sexes, which is enclosed (protologically and soteriologically) by the relation to Christ (cf. 1 Cor. 3:23). Paul seeks to establish the transparent inequality of male and female ${ }^{34}$ in worship over against a (assumed enthusiastic) disregard for gender differences in Corinth (cf. 1 Cor. 14:33-36). In verse 8f., he establishes the conventional hierarchy of the sexes through the Biblical creation arrangement. This argumentation contradicts the conception of equality (and exegetical aspiration for coherence).

As a counterbalance ( $\left.\pi \lambda \eta_{\eta}^{\prime}\right)$ ), in 1 Corinthians 11:11f., Paul describes the social relationship of male and female in the communion of the baptised as a reciprocal dependent relationship. However, here again the aspect of equality of the sexes is absent, ${ }^{35}$ but the attached prepositional phrase $\dot{\varepsilon} v$ xupi $\omega$ in 1 Corinthians 11:11 defines the scope of their mutuality. Verse 12 anchors this relationship with a reference to their ontological connection to the God-given order of creation as a constitutive difference. The male and the (in this perishing age) subordinated female are dependent upon each other for existence and they have a common origin and redemptive goal in God (cf. 1 Cor. 8:6), i.e. in the status before the emergence of a sexual bipolarity and gender inequality. The phrase $\tau \dot{\alpha} \delta \dot{\varepsilon} \pi \dot{\alpha} \nu \tau \alpha$ with the definite article dissolves the contradiction. Understood in this way, Paul recognises no contradiction between the necessary differences and divergent roles, due to the Biblical order of creation and the social equality of the common identity $\dot{\varepsilon} \nu$ X

\section{EQUALITY AND ESCHATOLOGICAL HOPE IN 1 CORINTHIANS}

The exegetical observations in the study of the category of eschatological equality in 1 Corinthians lead to a series of answers to the questions posed

33 Marriage merely fulfils the function of a remedium concupiscentiae. Cf. Külling (2008:52f.).

34 Cf. Josephus (Ap II 201).

35 Cf. the theological reason for this hierarchy in 1 Cor. 11:8. 
at the beginning. First, regarding Jews and Greeks, one must differentiate between their negatively connoted descriptive equality as classes in the world, i.e. as integral parts of the perishing xó ${ }^{2}$ os (1 Cor. 1:21), and their salvific equality as members of a new ecclesiologal entity $\dot{\varepsilon} \nu$ Xp (cf. Becker 1992:400f.). The soteriologically decisive criterion for their very fate is not their primacy through election, but solely their relation to the word of the cross. Secondly and comparably, equality exists with regard to freedom and slavery, disregarding their social reality, which encompasses the congregation and in which they participate, fundamentally in their relation to Christian existence. The alternative for the individual and for his behaviour is either to perish as $\delta 0 \tilde{\nu} \lambda \circ \alpha_{\alpha} \dot{\alpha} \nu \rho \omega \dot{\omega} \pi \omega \nu$ or to participate in the new salvific reality within the new social identity of the change of dominion and the new status as $\delta \circ \tilde{\lambda} \lambda o^{\prime}$ Xp the latter can lead freemen and slaves in the congregation to encounter each other as equals in a dimension of communicative communion. Thirdly, regarding the equality of male and female, one must distinguish between their task as created beings according to the order of creation and the eschatological overcoming of the bipolarity of the sexes in the

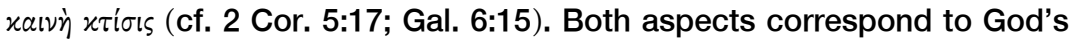
original salvation plan. Therefore, the gradual inequality of the sexes (also within the ecclesial area of life in the tension between the order of creation and the order of redemption) is not annulled $\dot{\varepsilon} \nu$ Xp $\sigma \tau \tilde{\omega}$, but will have no function regarding the hope of consummation in the coming kingdom.

In summary: With respect to social equality of Jews and Greeks, freemen and slaves, and male and female, although Paul views the coming world as already present, the actual differences between these antipodes should not be annulled or reversed in the Corinthian congregation. Paul's overarching situational argumentation is the re-establishment of the unity in Corinth. A fundamental and structural reform of the worldly political and social relations is, however, not a topic in, and of itself; nor as part of his overall goal. Paul's charismatic congregational model does not intend to annul or invert the existing order or the differences in presuppositions, thereby creating a new social theory. Rather he seeks the relativisation of the given social order by God's present saving power through the Christ event, which assimilates and creates unity and reconciliation. This saving power should manifest itself in the ecclesiastical praxis of the Corinthians and their eschatological accountability to one another. On the whole, the following statement is applicable: The Christian existence is possible in all variety and in every status. Therefore, the prescriptive social equality of Christians in Corinth, which Paul espouses, is not subject to the values and norms of this world, but radically redefines these values and norms. However, such a paradoxical ideal of equality is not escapist, 
but formulates a concrete, albeit, in the Christian existence, imperfect

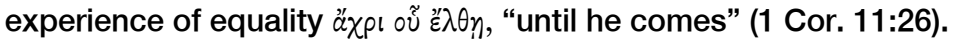

\section{BIBLIOGRAPHY}

BECKER, J.

1992. Paulus. Der Apostel der Völker. Tübingen: Mohr Siebeck.

$\mathrm{KoCH}, \mathrm{T}$.

1987. Gleichheit I. Theologisch. EStL 1(3):1177-1182.

KRATZ, R.G.

2006. Heiligkeit. HGANT:242f.

KüLLING, H.

2008. Ehe und Ehelosigkeit bei Paulus, eine Auslegung zu 1. Korinther 6,12-7,40.

Zürich: TVZ.

LAMPE, P.

2013. Erster Korintherbrief. In: F.W. Horn (ed.), Paulus Handbuch (Tübingen: Mohr Siebeck), pp. 172-185.

LANG, F.

1994. Die Briefe an die Korinther. Göttingen: Vandenhoek und Ruprecht. NTD 7.

LOADER, W.

2004. The Septuagint, sexuality, and the New Testament. Grand Rapids, MI: Eerdmans.

2012. The New Testament on sexuality. Grand Rapids, MI: Eerdmans.

LÜHRMANN, D.

1978. Der Brief an die Galater. Zürich: Theologischer Verlag. ZBK.NT 7.

MARTIN, D.B.

1995. The Corinthian body. New Haven, CT/London: Yale University Press.

Pollmann, I.

2012. Gesetzeskritische Motive im Judentum und die Gesetzeskritik des Paulus. Göttingen: Vandenhoek und Ruprecht. NTOA/StUNT 98.

SCHMELLER, T.

1995. Hierarchie und Egalität, eine sozialgeschichtliche Untersuchung paulinischer Gemeinden und griechisch-römischer Vereine. Stuttgart: Verlag Katholisches Bibelwerk. SBS 162.

SCHNELLE, U.

2003. Paulus, Leben und Denken. Berlin/New York: De Gruyter.

2013. Taufe als Teilhabe an Christus. In: F.W. Horn (ed.), Paulus Handbuch (Tübingen: Mohr Siebeck), pp. 332-337. 
Seluin, G.

1987. Hauptprobleme des Ersten Korintherbriefes. ANRW II 25.4:2940-3044.

SISSA, G.

2008. Sex and sensuality in the Ancient World. London: Yale University Press.

STRECKER, C.

1999. Die liminale Theologie des Paulus. Zugänge zur paulinischen Theologie aus kulturanthropologischer Perspektive. Göttingen: Vandenhoek und Ruprecht. FRLANT 185.

WOLTER, M.

2011. Paulus, ein Grundriss seiner Theologie. Neukirchen-Vluyn: Neukirchner.

ZeLLeR, D.

2010. Der erste Brief an die Korinther. Göttingen: Vandenhoek und Ruprecht. KEK 5.

ZiMMERMANN, R.

2013. Körperlichkeit, Leiblichkeit, Sexualität, Mann und Frau. In: F.W. Horn (ed.), Paulus Handbuch (Tübingen: Mohr Siebeck), pp. 378-385.

Keywords

Apostle Paul

1 Corinthians

Social equality
Trefwoorde

Apostel Paulus

1 Korintiërs

Sosiale gelykheid 